\title{
Stranded beluga (Delphinapterus leucas) calf response and care: reports of two cases with different outcomes
}

\author{
Caroline E.C. Goertz, ${ }^{1}$ Kathy Woodie, ${ }^{1}$ Brett Long, ${ }^{1}$ Lisa Hartman, ${ }^{1}$ Eric Gaglione, ${ }^{2}$ Dennis Christen, ${ }^{2}$ Tonya \\ Clauss, ${ }^{2}$ Jennifer Flower, ${ }^{3}$ Allison Tuttle, ${ }^{3}$ Carey Richard, ${ }^{3}$ Tracy A. Romano, ${ }^{3}$ Todd Schmitt, ${ }^{4}$ Eric Otjen, ${ }^{4}$ Steve \\ Osborn, ${ }^{5}$ Steve Aibel, ${ }^{6}$ Tim Binder, $, 6,7$ William Van Bonn, ${ }^{6}$ Manuel Castellote,${ }^{8,9}$ T. Aran Mooney, ${ }^{10}$ Sophie \\ Dennison-Gibby, ${ }^{11}$ Kathy Burek-Huntington ${ }^{12}$ \& Teresa K. Rowles ${ }^{13}$
}

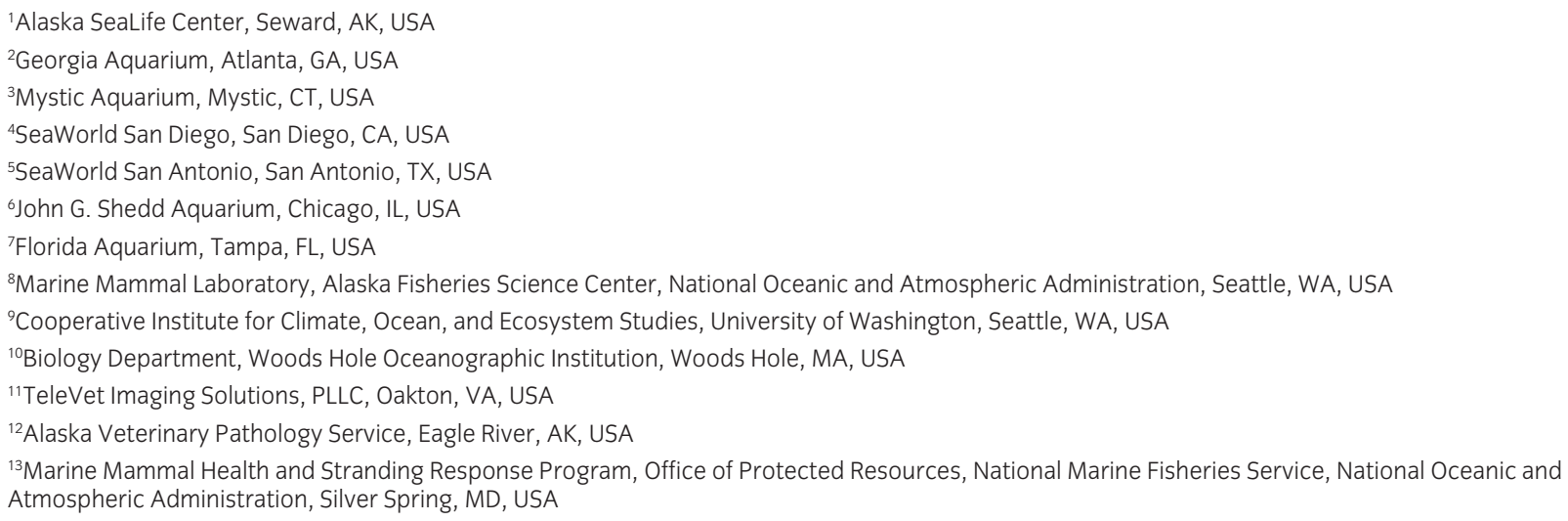

\begin{abstract}
Given the remote, rugged areas belugas typically inhabit and the low rehabilitation success rate with any cetacean, it is rare to have the opportunity to rescue a live-stranded beluga. The Alaska SeaLife Center cared for two stranded beluga calves with two different outcomes. In 2012, a neonatal male beluga calf (DL1202) stranded following intense storms in Bristol Bay. In 2017, a helicopter pilot discovered a stranded male beluga calf (DL1705) during a flight over Cook Inlet. The Alaska SeaLife Center transported both calves for rehabilitation and utilized supportive care plans based on those for other species of stranded cetaceans and care of neonatal belugas at zoological facilities. Diagnostics included complete blood counts, serum chemistries, microbial cultures, hearing tests, imaging and morphometric measurements to monitor systemic health. Treatments included in-pool flotation support; antimicrobials; gastrointestinal support; and close monitoring of respirations, urination, defecation and behaviour. After three weeks of supportive care, the Bristol Bay calf (DL1202) succumbed to sepsis secondary to a possible prematurity-related lack of passive transfer of antibodies. After seven weeks, the Cook Inlet calf (DL1705) recovered and all medications were discontinued. Unable to survive on his own, he was declared non-releasable and placed in long-term care at a zoological facility, to live with other belugas. Aspects and details from successful cases of cetacean critical care become important references especially vital for the survival of essential animals in small, endangered populations.
\end{abstract}

\section{Keywords}

Cetacean; neonate; nutrition; hand-rearing; critical care

\section{Correspondence}

Caroline E.C. Goertz, Alaska SeaLife Center, PO Box 1329, Seward, AK 99664, USA. E-mail: carrieg@alaskasealife.org

\author{
Abbreviations \\ AEP: audio evoked potentials \\ ASLC: Alaska SeaLife Center \\ $\mathrm{Cl}$ : Cook Inlet \\ $\mathrm{CT}$ : computed tomography \\ $\mathrm{K}_{2}$ EDTA: potassium \\ ethylenediaminetetraacetic acid \\ MMHSRP: Marine Mammal Health and \\ Stranding Response Program \\ NOAA: National Oceanic and Atmospheric \\ Administration \\ rpm: rotations per minute \\ SLE: St. Lawrence Estuary
}

This article is part of the special cluster Beluga whales (Delphinapterus leucas): knowledge from the wild, human care and TEK, which has been funded by Mystic Aquarium, CAFF and the Norwegian Ministry of Climate and Environment.

To access the supplementary material, please visit the article landing page 


\section{Introduction}

Cetacean rehabilitation has a low success rate. Over a 25-year period (1977-2002), out of 70 cetaceans that were stranded alive in California, 60 (86\%) ultimately died. Of the remaining animals, two (3\%) were relocated and immediately released, five $(7 \%)$ were rehabilitated and released, and three (4\%) were declared non-releasable and placed in zoological facilities (Zagzebski et al. 2006). A more recent review of the national MMHSRP catalogue listed 396 cetacean rescues from 2000 to 2016 , with $294(74 \%)$ ultimately dying or euthanized, 58 (15\%) being released and $44(11 \%)$ transferred to permanent zoological care (NOAA Fisheries MMHSRP National Database unpubl. data); this shows an improved survival rate, from $14 \%$ in the earlier California data compared to $26 \%$ in the more recent review of the national database.

There have been few attempts at rehabilitating belugas. Given the remote, rugged areas belugas typically inhabit, it is rare to encounter and be able to coordinate the rescue of a live-stranded beluga. In the 1990s, there were unsuccessful attempts to rehabilitate beluga calves from the SLE (De Guise et al. 1992), all of which were either euthanized or died within 10 days (Michaud et al. 2020). Since that time, rescuers in SLE have encountered three additional calves and reunited them with pods of SLE belugas (Michaud et al. 2020). Because these calves were not tagged and were only followed for a few hours, it is unknown if they ultimately survived. A subadult SLE beluga was discovered in poor condition upriver; supportive care was provided while the beluga was successfully translocated back to its normal range, tagged and released. This animal was tracked and re-spotted alive approximately one year later (Le Net et al. 2019).

Given the importance of the survival of each reproductive individual, rehabilitation efforts in threatened and endangered populations are also important. In addition, these cases provide valuable opportunities to better understand health threats to those populations as well as for refining medical and husbandry practices during the critical care period. Ex situ options for cetacean conservation are receiving more attention with focused meetings on the topic (Ex Situ Options for Cetacean Conservation Workshop, Nuremberg, 14-18 December 2018) and have been specifically considered for the vaquita (Phocoena sinus; Jaramillo-Legorreta et al. 2007) and the baiji (Lipotes vexillifer; Wang et al. 2006).

The CI population of belugas (Delphinapterus leucas) is listed as endangered and continues to decline for unknown reasons (NMFS 2008, 2016). With only 279 belugas as of the 2018 abundance estimate (Shelden $\delta$ Wade 2019), every individual is essential to the population. Despite the historical difficulties in rehabilitating cetaceans, the ASLC in Seward, Alaska, attempted to rehabilitate a stranded beluga calf from Bristol Bay in 2012, as well as one from CI in 2017. One calf recovered and one succumbed. This report describes these two cases, including details of medical and husbandry care, diagnostic findings and additional factors that likely influenced the different outcomes for these two calves.

\section{Methods}

\section{Stranding circumstances}

Mid-afternoon on 18 June 2012, following a night of extreme storms and heavy surf, beach walkers observed a small beluga calf (DL1202) struggling at the water line, rolling in heavy surf close to South Naknek, off Bristol Bay, Alaska $(58.72$ N, 156.99 W). A rescue was authorized after unsuccessful attempts were made to return the animal to deeper water, and local observers confirmed the absence of any adult belugas in the area. The male calf was transported by a fixed wing aircraft and truck to ASLC for attempted rehabilitation.

Mid-afternoon on 30 September 2017, a small beluga (DL1705) was observed above the waterline on Trading Bay, south of McArthur River, on the west side of CI (60.88 N, 151.73 W), Alaska, by an Alaskan State Trooper and NOAA Law Enforcement in a helicopter. Upon closer inspection, the beluga was determined to be a live calf with moderate external physical trauma. Attempts to encourage the calf to swim into the inlet were unsuccessful, and adult belugas were not observed in the area during a subsequent overflight to pick up a veterinarian for an examination of the calf. The stranded beluga was assessed to be a dependent male calf with injuries deemed non-life-threatening, prompting recommendation for rehabilitation. Rescue was authorized, and the calf was transported by helicopter and truck to ASLC for attempted rehabilitation.

\section{Aging}

Animals were aged based on morphological characteristics and physiological parameters summarized in Fig. 1 and Table 1 .

\section{Housing and environmental parameters}

DL1202 was housed in an outdoor $6 \mathrm{~m}$ circular pool with a depth of up to $1.8 \mathrm{~m}$ (53 $347 \mathrm{~L})$. DL1705 was initially housed in an interior $4.6 \mathrm{~m}$ circular pool with a depth up to $1.2 \mathrm{~m}(20013 \mathrm{~L})$; this pool room had a large bay exterior door that was increasingly left open as time progressed to acclimate the calf to outdoor temperatures. After five 

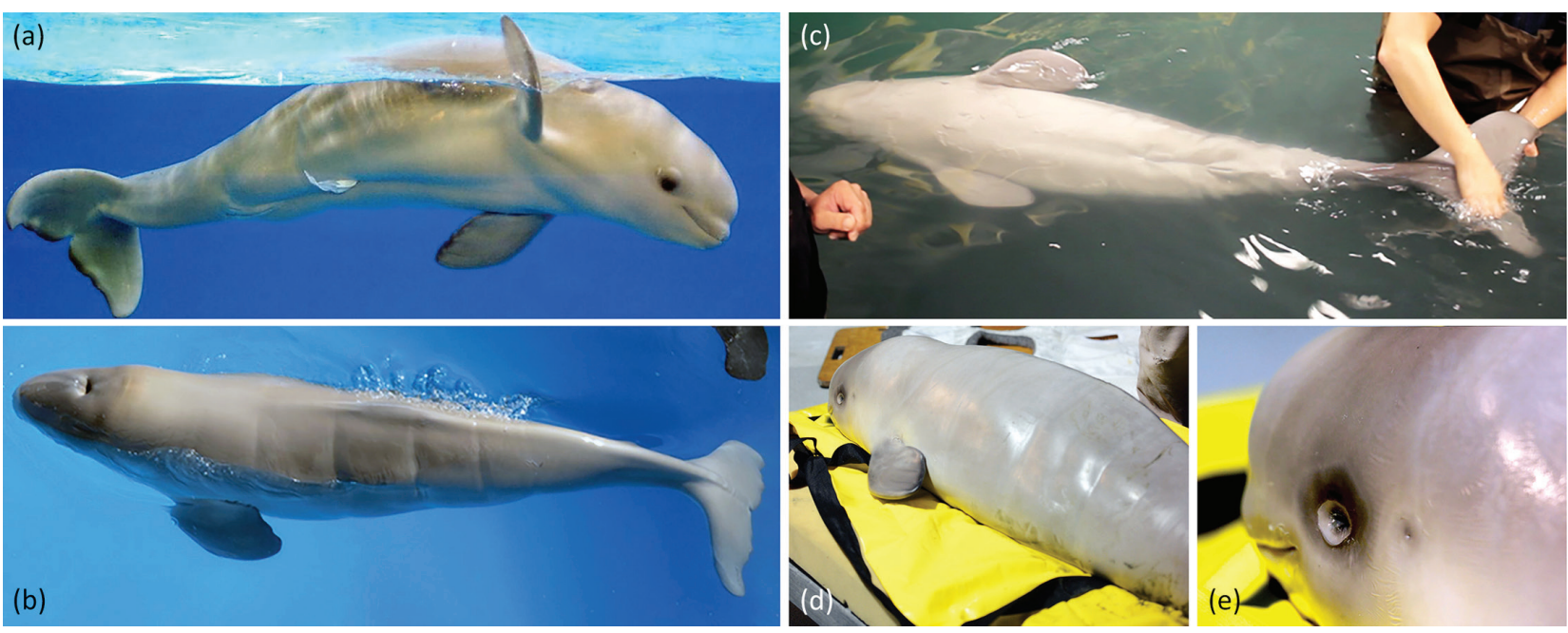

(b)

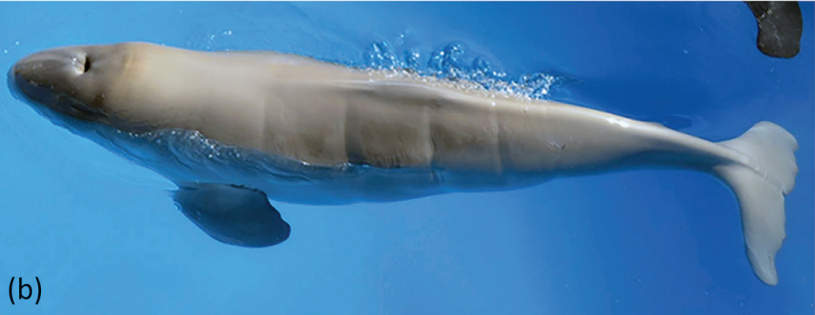

Fig. 1 Physical attributes used to determine age in stranded beluga calves (Delphinapterus leucas). DL1202 had (a) an umbilical sheath containing cord remnants and dark periocular pigmentation as well as (b) foetal folds. DL1705 did not have (c) an umbilical cord or sheath but did have (d) foetal folds and (e) dark periocular pigmentation.

Table 1 Parameters used for aging the stranded beluga calves based on data and observations from beluga, other cetaceans and other mammalian neonates, as noted in the description.

\begin{tabular}{|c|c|c|c|c|c|}
\hline \multirow{2}{*}{ Characteristic } & \multirow{2}{*}{ Description (reference) } & \multicolumn{2}{|c|}{ DL1202, Bristol Bay } & \multicolumn{2}{|c|}{ DL1705, Cl } \\
\hline & & Findings & Age (days) & Findings & Age (days) \\
\hline Admission date & $\begin{array}{l}\text { Beluga neonates have been photographed in Cl as early as mid- } \\
\text { July and as late as October (McGuire \& Stephens 2017) }\end{array}$ & 18 June 2012 & - & $\begin{array}{l}30 \text { September } \\
2017\end{array}$ & - \\
\hline Length & $\begin{array}{l}\text { Beluga age estimated from length using formula: } \\
{\left[51.5+(4.451 \times T L)-\left(0.0106 \times \mathrm{TL}^{2}\right)\right]-478 \pm 8.6 \text { d (Dalton } 2007 \text {; }} \\
\text { Robeck et al. 2015) }\end{array}$ & $144 \mathrm{~cm}$ & $\begin{array}{c}-5.4 \\
(-14.0-3.2)\end{array}$ & $162 \mathrm{~cm}$ & $\begin{array}{l}16.4 \\
(7.8-25.0)\end{array}$ \\
\hline Weight & $\begin{array}{l}\text { Average } 64 \mathrm{~kg} \text { (55-65). Smallest surviving beluga calf in } \\
\text { zoological facilities was } 53.6 \mathrm{~kg} \text { (Dalton 2007) }\end{array}$ & $45.5 \mathrm{~kg}$ & Premature & $64 \mathrm{~kg}$ & Full term \\
\hline Meconium passage & $\begin{array}{l}\text { Meconium, or foetal faeces, is typically passed within 1-3 days } \\
\text { after birth in humans before transitioning to normal faeces } \\
\text { (Bekkali et al. 2008; Lakshmanan \& Ross 2008) }\end{array}$ & Observed & $<3$ & Not observed & $>3$ \\
\hline Umbilicus healing & $\begin{array}{l}\text { Umbilical cord remnant present at birth, falls off ca. } 1 \text { week, } \\
\text { healed at body wall ca. } 3 \text { weeks in bottlenose dolphins and har- } \\
\text { bour seals (Phoca vitulin; Dierauf et al. 1984; Dearolf et al. 2000) }\end{array}$ & Cord present & $<3$ & $\begin{array}{l}\text { No cord, healed } \\
\text { at body wall, } \\
\text { divot present }\end{array}$ & $>14$ \\
\hline Foetal folds & $\begin{array}{l}\text { Skin indentations on flank due to compression in utero, smooth } \\
\text { out by } 2 \text { months in bottlenose dolphins and beluga (Dearolf et } \\
\text { al. 2000; Krasnov et al. 2009) }\end{array}$ & Present, pronounced & $<14$ & Present, mild & $7-21$ \\
\hline Flukes & $\begin{array}{l}\text { Floppy/wrinkly flukes firm up by ca. } 2 \text { week in bottlenose dol- } \\
\text { phins (Dearolf et al. 2000) }\end{array}$ & Soft, somewhat curved & $<14$ & Firm, fairly flat & $>14$ \\
\hline $\begin{array}{l}\text { 'Black eye'-'eye } \\
\text { ring' }\end{array}$ & $\begin{array}{l}\text { Variably present for a couple of weeks for 'black eye,' several } \\
\text { months for 'eye ring' in beluga (R. Michaud, pers. comm.) }\end{array}$ & Present & $<60$ & Present & $<60$ \\
\hline Post-natal moult & $\begin{array}{l}\text { Variable, occurs ca. } 1-2 \text { months post-parturition in beluga } \\
\text { (S. Aibel, pers. comm.) }\end{array}$ & $\begin{array}{l}\text { Not observed, lanugo } \\
\text { noted post-mortem }\end{array}$ & $<30$ & $\begin{array}{l}\text { Started } 5 \text { days } \\
\text { post-admission }\end{array}$ & $30-60$ \\
\hline Bilirubin & $\begin{array}{l}\text { Hyperbilirubinemia seen in neonates due to liver immaturity } \\
\text { and foetal haemoglobin turnover, more pronounced with } \\
\text { prematurity, decreases with age, resolves in 1-2 weeks in } \\
\text { harbour seals, bottlenose dolphins and harbour seals (Dierauf } \\
\text { et al. 1984; Feinholz \& Atkinson 2000; Morgan et al. 2009) }\end{array}$ & $2.8 \mathrm{mg} / \mathrm{dl}$ & $<7$ & $0.7 \mathrm{mg} / \mathrm{dl}$ & $>10$ \\
\hline $\begin{array}{l}\text { Swim pattern } \\
\text { Histopathology } \\
\text { Summary }\end{array}$ & & $\begin{array}{l}\text { Uncoordinated, corking } \\
\text { Foetal structures } \\
\text { Premature 2-day-old }\end{array}$ & Premature & $\begin{array}{l}\text { Smooth arcs } \\
\text { Not applicable } \\
\text { Full-term } \\
\text { 16-day-old }\end{array}$ & NA \\
\hline
\end{tabular}


weeks, DL1705 was transferred to an outdoor pool that could be managed at variable depths. Initially, the calf was kept in an area that was a half-circle with a radius of about $4.6 \mathrm{~m}$ at $0.9 \mathrm{~m}$ deep. About two weeks later, the pool was reconfigured to allow access to a $16.1 \mathrm{~m} \times 9.1 \mathrm{~m}$ oval mostly at $0.9 \mathrm{~m}$ but partially at $1.8 \mathrm{~m}$ deep. After another two weeks, the water level was raised to $1.8 \mathrm{~m}$ and then $2.7 \mathrm{~m}$ with a total capacity of $286650 \mathrm{~L}$.

Pools were supplied with natural seawater from wells passively filled during high tides from Resurrection Bay approximately $60 \mathrm{~m}$ below the surface and $210 \mathrm{~m}$ from the shore. Once mechanically filtered, seawater was distributed to pools as needed. Depending on the pool, water was set up to be flow through or was recirculated through skimmers at a rate to ensure a minimum of two complete turnovers daily. A combination of heated salt and fresh city water was added in a side stream to achieve the desired temperature, which ranged $15.6-21.7^{\circ} \mathrm{C}$ for DL1202 and 10.6 to $21.1^{\circ} \mathrm{C}$ for DL1705 while inside. Pool salinity was monitored multiple times a day, and the relative flows of seawater and freshwater were adjusted as needed to keep the water at or above 24 ppt. After DL1705 was moved outside, supplementation of heated water was reduced and ultimately discontinued, and water temperature fluctuated with ambient conditions from 5.0 to $10.00^{\circ} \mathrm{C}$. Coliform testing was done weekly, consistent with Animal Welfare Act requirements. Additional measured parameters included water temperature and, when city water was being added, chlorine, $\mathrm{pH}$ and salinity.

Lighting was predominantly natural ambient light, supplemented with artificial sources for staff safety and during medical and husbandry procedures. Outdoor pools were partially shaded by portions of the building and surrounding mountains.

Both calves were under strict quarantine, with their own dedicated staff and spaces. Food preparation, area cleaning and equipment sanitation were consistent with Animal Welfare Act standards. DL1705 cleared quarantine five weeks after admission following recovery from his presenting health problems and successfully passed screening tests for infectious diseases of concern.

\section{Nutrition}

Both calves initially received electrolytes, nutritional supplements and fluids mixed with increasing concentrations of artificial milk-replacer formula, ground herring and salmon oil (Supplementary Table S1) via orogastric intubation, which was based on a formula developed for hand-rearing neonatal beluga calves at zoological institutions when maternal care was insufficient (Winhall 2012). The calves were lightly restrained, with just enough support to keep them stationary, and a foal feeding tube was passed orally to the stomach. Using syringes, oral medications were mixed into a slurry and slowly injected down the tube, followed by calf feeding syringes of formula warmed to $35-37.7^{\circ} \mathrm{C}$. While DL1202 was never successful at taking formula from a bottle, DL1705 quickly learned to voluntarily suckle from the tube, and subsequently, a bovine nipple on a bottle was utilized to deliver the formula without the need for any restraint. The initial voluntary feedings were inefficient, necessitating utilization of both methods until the calf could ingest enough from bottles to maintain an appropriate rate of weight gain with voluntary feeding alone.

\section{Husbandry and veterinary care}

Staffing for both calves included around the clock care by one to three people with extensive beluga, cetacean rehabilitation and/or neonatal cetacean experience; additional staff provided assistance for specific procedures or tasks as needed. The onsite care team was supported by consultants from zoological facilities that care for belugas, federal biologists and other medical and veterinary experts. The daily routine included body measurements, food preparation, multiple feedings, detailed animal monitoring and observational record keeping (including respiratory rate, defecations, behaviour and treatments), enrichment, pool parameter monitoring and cleaning. Veterinary exams were initially done twice a day and later once a week with daily visual check-ins. Various biological samples (blood, blowhole and breath, gastrointestinal contents and faeces, by techniques listed below), diagnostic images, body weights and other morphometric measurements were initially collected several times a week. As DL1705 stabilized, sample collection frequency decreased. Both calves were treated with antibiotics, antifungals and gastrointestinal modifiers (Supplementary Table S2) using published doses (Stoskopf et al. 2001), upon the recommendation of consulting veterinarians or based on published cases (Reidarson et al. 2001; Sweeney et al. 2010; Osborn et al. 2012; Winhall 2012; Flower et al. 2018).

\section{Sample collection, processing and storage}

Following collection, samples were either analysed promptly as described below or transferred to appropriate containers and stored in a $-80^{\circ} \mathrm{C}$ freezer until sent for further analysis typically within a few days to weeks unless otherwise noted. After the skin was disinfected with alcohol, blood was collected from the periarterial venous rete on the dorsal or ventral tail fluke using a $1.3 \mathrm{~cm} \mathrm{19-21}$ gauge butterfly catheter (Becton, Dickinson \& Co.) directly 
into plain, serum separator, sodium heparin and $\mathrm{K}_{2}$ EDTA Vacutainer® tubes (BD Biosciences); or, using a syringe, blood was immediately transferred into appropriate tubes. Whole blood was kept at room temperature and analysed within $4 \mathrm{hr}$. Plain and serum separator tubes were allowed to clot at room temperature, and then serum was separated by centrifugation for $5 \mathrm{~min}$ at $4000 \mathrm{rpm}$. Serum biochemical analyses were performed, or serum was pipetted in $1 \mathrm{ml}$ aliquots into cryovials for storage. Sodium heparin and $\mathrm{K}_{2}$ EDTA tubes were centrifuged for $5 \mathrm{~min}$ at $4000 \mathrm{rpm}$ to separate plasma, which was pipetted in $1 \mathrm{ml}$ aliquots into cryovials. Swabs of the rectum, wounds, skin and blowhole were collected and placed in Amies or Cary-Blair media (Becton, Dickinson \& Co.), refrigerated and sent within $24 \mathrm{hr}$ to a commercial microbiology laboratory for microbial pathogen screening. Additional swabs were collected and stored in viral transport media (Remel MicroTest M4RT Kit, Medex Supply) or were stored without media and frozen at $-20^{\circ} \mathrm{C}$ until submitted for viral screening. Respiratory cytology samples were obtained by holding a slide attached to a Petri dish over the blowhole during multiple breaths. Additional breath condensate was collected by holding a 50-ml conical tube or a Petri dish with a nylon membrane attached over the blowhole for several breaths. Gastric samples were collected using a feeding tube primarily prior to tubing fluids or formula but occasionally as a separate diagnostic sampling procedure. Cytology slides of gastric samples were prepared immediately. Additional samples were refrigerated at $4^{\circ} \mathrm{C}$ or frozen at $-80^{\circ} \mathrm{C}$. Skin was collected when wound edges were trimmed, or opportunistically, as it fell off when moulting and transferred to cryovials. Faecal samples obtained opportunistically and/or during enema treatments were transferred to cryovials. Tissues from DL1202 collected for histopathology were preserved in 10\% neutral buffered formalin and shipped to Histology Consulting Services (Everson, WA) for processing. Paraffin-embedded sections were cut at $5 \mu \mathrm{m}$ and stained with haematoxylin and eosin.

\section{Laboratory analysis}

Complete blood counts, serum chemistries and faecal parasite analyses were performed at ASLC's in-house clinical laboratory. Two microhematocrit tubes were centrifuged for $6 \mathrm{~min}$ at $14000 \mathrm{rpm}$ to determine packed cell volume using a micro-capillary reader (International Equipment Company) and to aid in the identification of haemoparasites. Blood smears were prepared, dried, fixed in methanol and stained using Wright-Giemsa (Henry Schein Animal Health) for manual white blood cell differential counts and to screen for haemoparasites. Complete blood counts were performed on ASLC's
IDEXX ProCyte Dx (DL1705) or Heska CBC Diff (DL1202) analyser, using whole blood. Serum chemistries were performed using ASLC's IDEXX VetTest 8008, except for iron and triglycerides, which were run on the Beckman Coulter AU480 Chemistry Analyzer at SeaWorld San Diego's in-house clinical laboratory. Serum protein electrophoresis was run at the Phoenix Central Laboratory on a Helena Protein Electrophoresis unit. The concentration of serum cortisol was determined by a chemiluminescent-immunoassay (Immulite, Siemens Healthcare Diagnostics) at Cornell University's Animal Health Diagnostic Center; serum samples from DL1705 were submitted within weeks of collection, whereas those from DL1202 were submitted in 2019 for retrospective analysis and comparison to DL1705's values. Serum and molecular samples were shipped on dry ice via express delivery to reference laboratories and research facilities or testing for evidence of disease or exposure to avian influenza at the Runstadler Laboratory (Spackman et al. 2002; Puryear et al. 2016), Brucella at Mystic Aquarium (Meegan et al. 2010) and the University of Illinois Veterinary Diagnostic Laboratory (Colegrove et al. 2016), herpesvirus at the University of Florida Zoological Medicine and Wildlife Disease Laboratory (Davison et al. 2017), cetacean morbillivirus at Athens Veterinary Diagnostic Laboratory (Saliki \& Lehenbauer 2001) and protozoal diseases (Neospora caninum, Toxoplasma gondii and Sarcocystis neurona) at the University of California, Davis (Miller et al. 2002). Culture swabs were submitted for aerobic bacterial culture at Providence Alaska Medical Center and Athens Veterinary Diagnostic Laboratory. Tissue slides (DL1202 only) were examined by an American College of Veterinary Pathology board-certified pathologist with marine mammal experience $(\mathrm{KBH}$, Alaska Veterinary Pathology Service), who provided histopathological diagnoses.

\section{Imaging}

Diagnostic thoracic and abdominal ultrasounds (E.I. Medical Imaging's IBEX Pro and CL3.8L (2.5-5 MHz) and MC8.0 (6-10 MHz) transducers) were performed and used to serially measure and monitor blubber depth (Cornick et al. 2016; Dennison \& Saviano 2018). Whole body CT scans were performed three times (12 October 2017, 16 November 2017 and 3 January 2018) for DL1705 for initial assessment and subsequent tracking to resolution of observed abnormalities. For CT, the calf was placed on foam and covered with moist sheets during scanning using a GE Lightspeed16 CT Scanner System. Helical scan mode, $120 \mathrm{kV}, 210 \mathrm{~mA}$ and pitch 1.75 were used for all studies. Slice thickness varied between studies 
with $1.25 \mathrm{~mm}$ used initially and $5.00 \mathrm{~mm}$ subsequently. For all studies, images were reconstructed using a soft tissue and bone reconstruction algorithm. The entire process-removing the calf from his pool, transportation to the hospital, scanning, transportation back and return to his pool-was approximately $30 \mathrm{~min}$. Between CT scan dates, radiographic images were obtained from DL1705 using a MiniXRay HF120/60HPPWV PowerPlus generator, Canon CXDI-70C wireless plate and VetRocket processing system. All CT and radiographic images were stored in DICOM format and were reviewed by an American College of Veterinary Radiology board-certified radiologist with marine mammal experience (SDG, TeleVet Imaging Solutions).

\section{Hearing test}

Hearing measurements were obtained only from DL1705 shortly after admission on 4-5 October 2017 and two months later on 5-6 December 2017 using AEP recording methods (Houser \& Finneran 2006; Finneran et al. 2007; Nachtigall et al. 2007; Mooney et al. 2012). All hearing examinations were conducted in the water at a depth of 1 $\mathrm{m}$, where the calf was gently held in place with its head freely moveable, similar to previously established methods with stranded and wild odontocetes (Nachtigall 2005; Castellote et al. 2014). Data collection, calibrations and analyses were designed to follow that of previous beluga AEP hearing studies and American National Standards Institute standards for measuring odontocete audiograms (Castellote et al. 2014; ANSI 2018; Mooney et al. 2018; Mooney et al. 2020). Briefly, these methods included amplitude modulated tones played using a jaw phone to limit any effect of head movement. Responses were measured from AEP suction cup electrodes placed just behind the blowhole (positive recording electrode), on the dorsal ridge (reference) and a ground located on the animal's caudal peduncle. Responses were amplified $10000 \times$ and filtered from 300 to $3000 \mathrm{~Hz}$. Calibrations were conducted at $1 \mathrm{~m}$ at the location of the two hearing tests while the animal was not there. Thresholds were determined using F-statistical methods. More details are presented by Mooney et al. (2020).

\section{Results}

Following the admission exam on 18 June 2012 and a review of physical and physiological findings, DL1202 was assessed to be approximately two days old (Fig. la, b, Table 1) largely on the basis of the state of his umbilicus and the passage of meconium. Additionally, being smaller than the smallest reported surviving calf in a zoological facility, prematurity was suspected. His swim

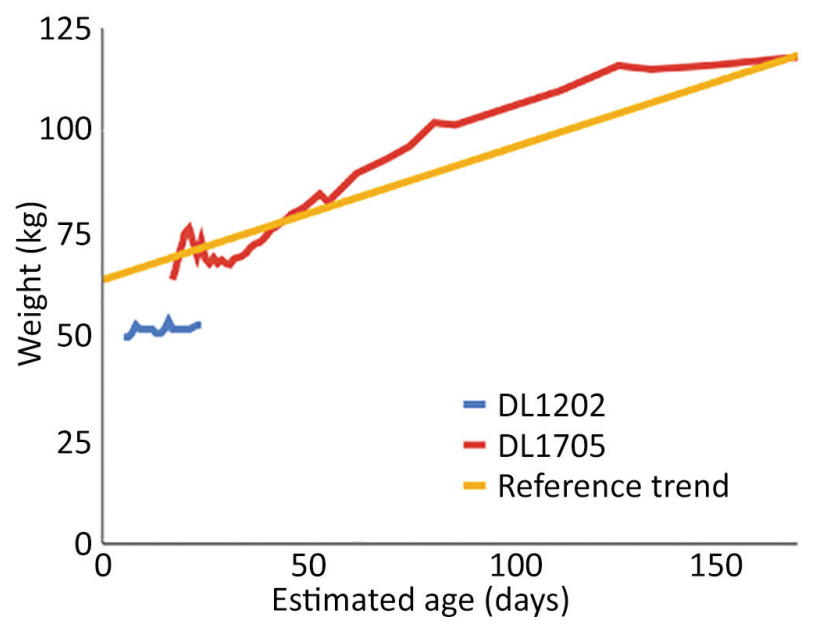

Fig. 2 Daily weights $(\mathrm{kg})$ in stranded beluga calves (Delphinapterus leucas) DL1202 and DL1705. Reference trend based on a median birth weight of $64 \mathrm{~kg}$ and an average weight gain of $0.32 \mathrm{~kg}$ per day of beluga calves born in aquaria (Dalton 2007).

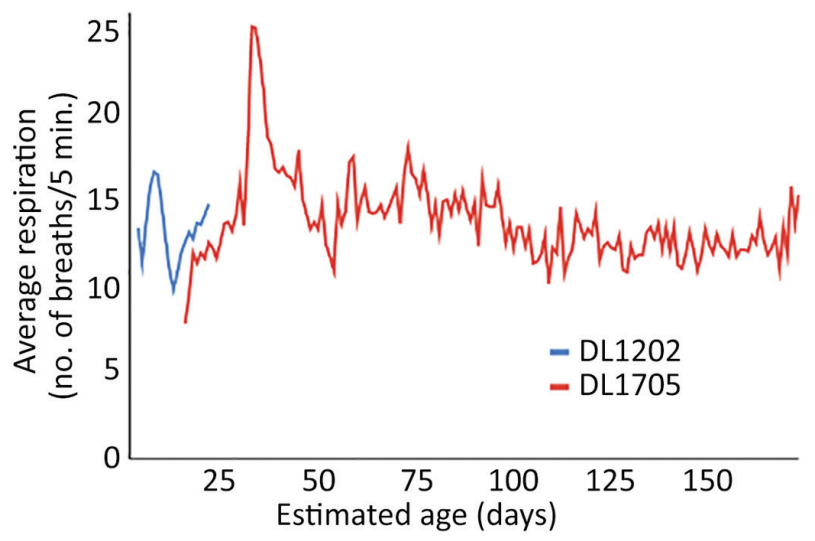

Fig. 3 Average daily respiration rate (number of breaths over 5-min time periods taken frequently throughout the day, then averaged) in stranded beluga calves (Delphinapterus leucas) DL1202 and DL1705.

pattern was initially uncoordinated, but he did not require assistance and over time he began to swim in smooth arcs through the water. His eyes were initially open and appeared normal; however, severe bilateral blepharospasm developed partway through his care precluding further voluntary examination. While he never successfully bottle-fed, he cooperated with his gavage feeds and initially gained weight (Fig. 2). Starting on 22 June 2012, he would sometimes float in a curved posture suggesting abdominal pain and had signs of constipation, delayed gastric emptying, gastrointestinal gas and increases in respiratory rate (Fig. 3). The feeding formula was diluted, and medications were changed, which not only helped to mitigate these problems but also resulted in weight loss. 
Clinical laboratory findings included nonregenerative anaemia, neutrophilia, bilirubinaemia and elevated alkaline phosphatase (Tables 2, 3, Supplementary Tables S3, S4). His initial beta and gamma globulins (Table 4) were low, though later increased slightly. A high level of cortisol at admission decreased to a normal level but was elevated during one period of severe gastrointestinal distress and shortly before death (Table 5). Tests for exposure to diseases of concern were negative. Outside of the periods of gastrointestinal distress, he would swim in a varied pattern using the whole pool, interacting with staff and enrichment items.

During his last day, he appeared increasingly disoriented, vomited and appeared to be experiencing an episode of delayed gastric emptying with mild increased respiratory effort. While attempts were being made to relieve the build-up of undigested formula from his stomach, he developed respiratory distress, subsequently vomiting and aspirating formula. Despite emergency therapy, the respiratory distress could not be reversed, and he succumbed on 8 July 2012.

A necropsy was performed the following day, and findings included significant changes in multiple organs. Bilateral roughened, inflamed ocular surfaces and corneal ruptures were accompanied by debris deep in the conjunctival fornix. There was a copious amount of serosanguinous fluid with fibrinous strands in the right hemithorax and pericardium as well as cloudy fluid in the abdomen. White fluffy material was adherent to the oesophagus. All sections of the gastrointestinal tract contained abundant digesta, without gaps, and were more than expected. Histopathological analysis of the tissues indicated he likely developed septicaemia secondary to or in conjunction with ruptured corneas, pleuropneumonia, bronchopneumonia and pericarditis. In some areas, there were plugs of fibrin in many of the alveoli and foamy macrophages suggestive of poor ciliary escalator or partial obstructions to outflow. Eosinophilic intranuclear inclusion bodies in the pharynx and tonsil as well as in the bone marrow were consistent with herpesvirus, though no further follow-up was pursued. Findings also included severe ulcerative fungal pharyngitis, esophagitis and gastritis, likely secondary to required antibiotic treatments and the immunologically weakened condition of the animal. This animal had several tissues that appeared more immature than expected of a full-term neonate, including foetal glomeruli, with no adult forms and poorly formed muscularis externa of the colon and the jejunum, which likely contributed to difficulty with effective movement of digesta. There was a distinct extra layer to the stratum corneum, which most likely represents a layer shed during the post-natal ecdysis.

Following the admission exam on 30 September 2017 and a review of physical and physiological

Table 2 Summary haematology values in stranded beluga calves (Delphinapterus leucas) DL1202 and DL1705. Quartile ranges of values (25-75\% quartiles around median) from 216 samples from 13 beluga of various ages residing at an aquarium are included for comparison (Gulland et al. 2018).

\begin{tabular}{|c|c|c|c|c|c|c|c|c|c|}
\hline \multirow[b]{3}{*}{$\mathrm{RBC}^{\mathrm{a}}\left(10^{6} / \mathrm{mm}^{3}\right)$} & \multicolumn{3}{|c|}{ DL1202 $(n=8)$} & \multicolumn{3}{|c|}{ DL1705 $(n=16)$} & \multicolumn{3}{|c|}{ Comparative values } \\
\hline & Min & - & Max & Min & - & Max & \multicolumn{3}{|c|}{ 25-75\% quartiles } \\
\hline & 2.90 & - & 3.38 & 2.60 & - & 3.39 & 3.0 & - & 3.4 \\
\hline $\mathrm{Hb}^{b}(\mathrm{~g} / \mathrm{dl})$ & 16.2 & - & 19.1 & 12.9 & - & 17.4 & 19.0 & - & 22.0 \\
\hline $\mathrm{PCV}^{\mathrm{c}}(\%)$ & 40 & - & 48 & 34 & - & 45 & 50 & - & 60 \\
\hline$M_{C} V^{d}(f l)$ & 133.7 & - & 144.7 & 121.7 & - & 137.2 & 163 & - & 185 \\
\hline $\mathrm{MCH}^{\mathrm{e}}(\mathrm{pg})$ & 54.2 & - & 58.6 & 48.5 & - & 55.9 & 59 & - & 66 \\
\hline $\mathrm{MCHC}^{f}(\mathrm{~g} / \mathrm{dl})$ & 40.5 & - & 42.6 & 38.3 & - & 41.0 & 36 & - & 38 \\
\hline Platelets $\left(10^{3} / \mathrm{mm}^{3}\right)$ & 75 & - & 189 & 113 & - & 300 & 60 & - & 130 \\
\hline 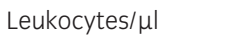 & 3100 & - & 6500 & 2650 & - & 7820 & 5000 & - & 9500 \\
\hline Neutrophil-band/ $\mu$ l & 0 & - & 504 & 0 & - & 164 & 0 & - & 0 \\
\hline 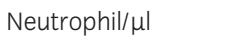 & 2046 & - & 5850 & 1844 & - & 4848 & 2580 & - & 5520 \\
\hline Lymphocyte/ul & 0 & - & 637 & 504 & - & 2274 & 1100 & - & 4150 \\
\hline Eosinophil/ $\mu$ l & 0 & - & 62 & 0 & - & 505 & 90 & - & 640 \\
\hline Basophil/ul & 0 & - & 0 & 0 & - & 115 & 0 & - & 0 \\
\hline NRBCs $s^{g}$ & 0 & - & 3 & 0 & - & 2 & 0 & - & 1 \\
\hline Reticulocytes \% & 1.0 & - & 3.8 & 1.0 & - & 6.9 & 0.3 & - & 0.8 \\
\hline RDW \% & 24.7 & - & 26.8 & 13.6 & - & 20.1 & \multicolumn{3}{|c|}{ Not reported } \\
\hline
\end{tabular}

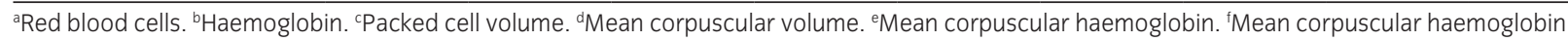
concentration. sNucleated red blood cells. 
Table 3 Summary of serum chemistry values in stranded beluga calves (Delphinapterus leucas) DL1202 and DL1705. Quartile ranges of values (25-75\% quartiles around median) from 216 samples from 13 beluga of various ages residing at an aquarium are included for comparison (Gulland et al. 2018).

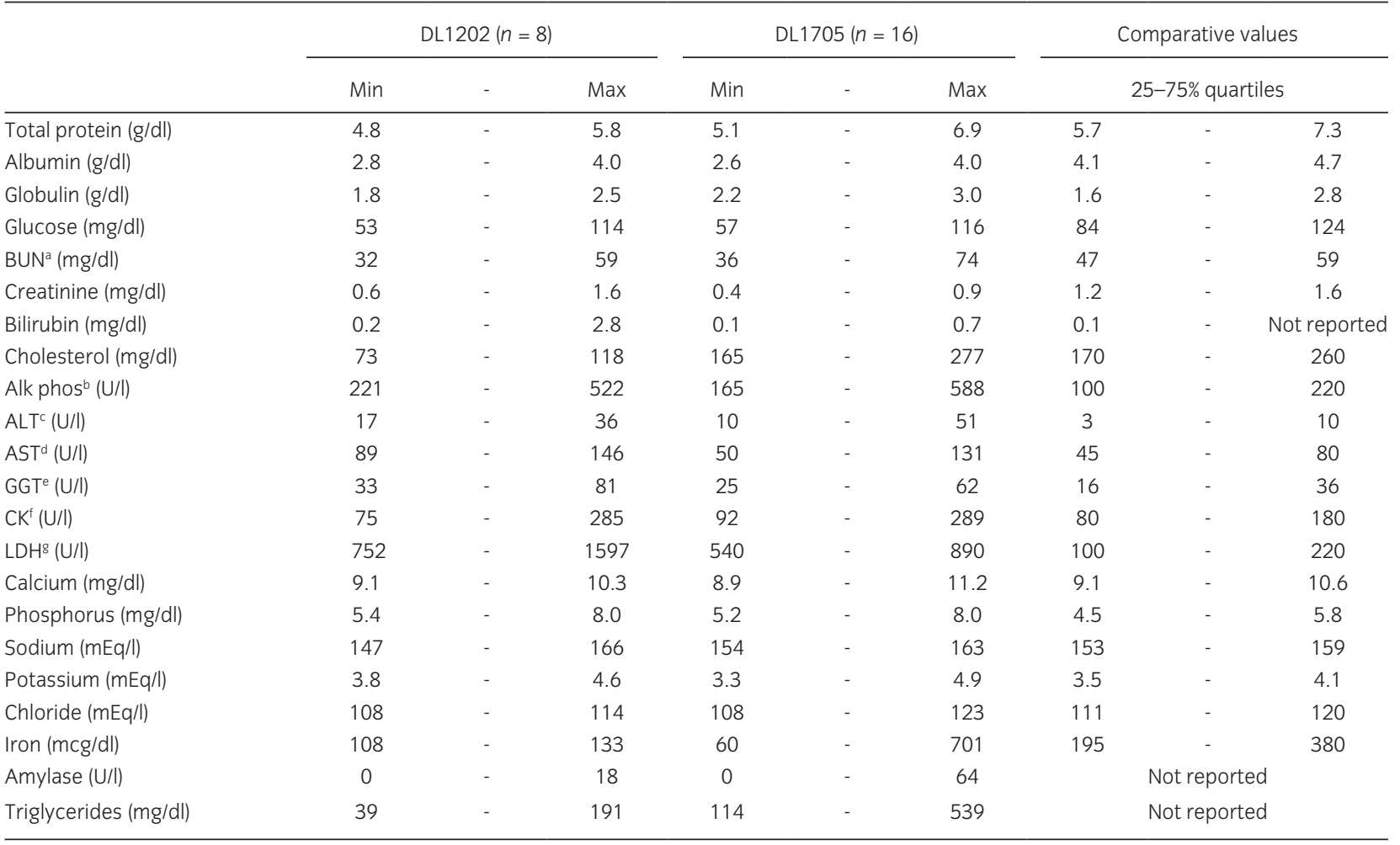

a Blood urea nitrogen. ${ }^{b}$ Alkaline phosphatase. ${ }^{c}$ Alanine transaminase. ${ }^{d}$ Aspartate aminotransferase. ${ }^{e}$ Gamma-glutamyl transferase. ${ }^{f}$ Creatine kinase.

s Lactate dehydrogenase.

Table 4 Serum protein electrophoresis values in stranded beluga calves (Delphinapterus leucas) DL1202 and DL1705. Comparative values were obtained from the ISIS/MedARKS/5.53 database (Teare 1991), queried on 19 June 2012 for normal values ( $N=1-6)$ from beluga calves less than 30 days old.

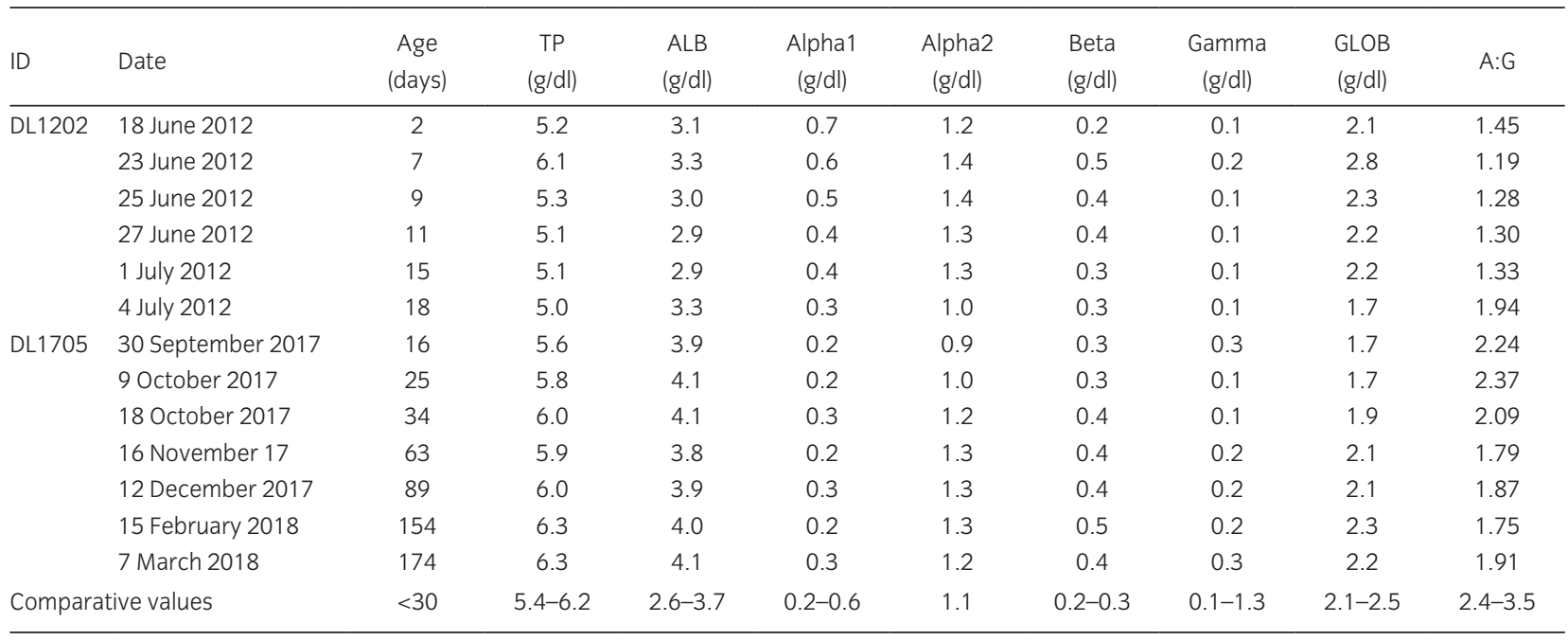

findings, DL1705 was assessed to be approximately 16 days old (Fig. 1c, d, e, Table 1) largely on the basis of his length. For the first 48 hours, he required flotation support provided by two staff members, and then only one before reliably swimming independently. By the third day, he was able to consume most of his formula through a bottle, but supplemental gavage feedings were required to maintain adequate weight gain of 
about $0.5 \mathrm{~kg} /$ day, which were continued until day 39 . Tracking weight gain (Fig. 2) was initially complicated by the post-natal ecdysis (Fig. 4) beginning on day 3 , resulting in the loss of more than $1 \mathrm{~kg}$ of skin a day as well as episodes of constipation which began on day 5 , though they were never as severe as DL1202. Blubber depth initially decreased (Fig. 5) but increased over time.

Table 5 Serum cortisol in stranded beluga calves (Delphinapterus leucas) DL1202 and DL1705 and a baseline level obtained from adult beluga in a zoological facility (Schmitt et al. 2010).

\begin{tabular}{|c|c|c|c|}
\hline Calf ID & Date & $\begin{array}{c}\text { Estimated age } \\
\text { (days) }\end{array}$ & Cortisol (ug/dl) \\
\hline \multirow[t]{7}{*}{ DL1202 } & 18 June $2012^{a}$ & 2 & 19.4 \\
\hline & 20 June 2012 & 4 & 9.07 \\
\hline & 23 June 2012 & 7 & 4.73 \\
\hline & 27 June 2012 & 11 & 19.4 \\
\hline & 1 July 2012 & 15 & 1.72 \\
\hline & 4 July 2012 & 18 & 4.14 \\
\hline & 8 July 2012 & 22 & 16.5 \\
\hline \multirow[t]{16}{*}{ DL1705 } & 30 September $2017^{a}$ & 16 & 11.600 \\
\hline & 4 October 2017 & 20 & 1.360 \\
\hline & 5 October 2017 & 21 & 1.010 \\
\hline & 9 October 2017 & 25 & 0.646 \\
\hline & 13 October 17 & 29 & 1.480 \\
\hline & 18 October 2017 & 34 & 2.630 \\
\hline & 22 October 2017 & 38 & 0.998 \\
\hline & 25 October 2017 & 41 & 0.780 \\
\hline & 29 October 2017 & 45 & 1.880 \\
\hline & 1 November 2017 & 48 & 0.754 \\
\hline & 7 November-2017 & 54 & 0.484 \\
\hline & 22 November 2017 & 69 & 2.080 \\
\hline & 12 Decemeber 2017 & 89 & 0.637 \\
\hline & 9 January 2018 & 117 & 0.801 \\
\hline & 15 February 2018 & 154 & 1.580 \\
\hline & 7 March 2018 & 174 & 0.913 \\
\hline $\begin{array}{l}\text { Comparative } \\
\text { values from an } \\
\text { adult }\end{array}$ & & & $1.8 \pm 0.71$ \\
\hline
\end{tabular}

${ }^{a}$ Admission.
Clinical laboratory findings included regenerative anaemia, neutropenia and elevated alkaline phosphatase (Tables 2, 3, Supplementary Tables S3, S4). His initial beta and gamma globulins (Table 4) were low but twice that of DL1202. Cortisol at admission was high but only about half that of DL1202, quickly decreased to a normal level and did not significantly change afterwards (Table 5). Tests for exposure to diseases of concern were negative, except for herpesvirus, which was not of clinical significance.

Hearing tests in October and December (Fig. 6) indicated that this beluga calf heard all frequencies tested (4-128 kHz) and showed sensitive hearing ( $<70 \mathrm{~dB})$ for a wide range of frequencies $(16-80 \mathrm{kHz})$. These findings were reflective of a healthy odontocete auditory system similar to many healthy belugas from the Bristol Bay population, the only other published data set of healthy, wild marine mammal hearing (Mooney et al. 2018). Both measurements were similar, showing continued auditory health of the animal throughout the rehabilitation period.

A CT scan on 12 October 2017 revealed peribronchial infiltrates suggestive of aspiration pneumonia (Fig. 7a), granular material within the gastrointestinal tract potentially due to sand ingestion during stranding, and intracranial ventriculomegaly indicating mild hydrocephalus (Fig. 7d). His behaviour and respiratory rate (Fig. 3) changed significantly on 17 October 2017, when his pattern of actively swimming, diving and interacting with staff switched to having increased buoyancy, spending more time logging at the surface, less time interacting with caretakers and breathing more rapidly. These changes, initially attributed to gastrointestinal distress, were likely due to pneumothorax. This was not diagnosed until his second CT scan on 16 November 2017, which revealed a left-sided pneumothorax without evidence of tension (Fig. 7b), resolution of the previous pneumonia and improved but not resolved intracranial ventriculomegaly. Over time, clinical progress was observed as buoyancy decreased, respirations normalized and the pneumothorax spontaneously resolved, as
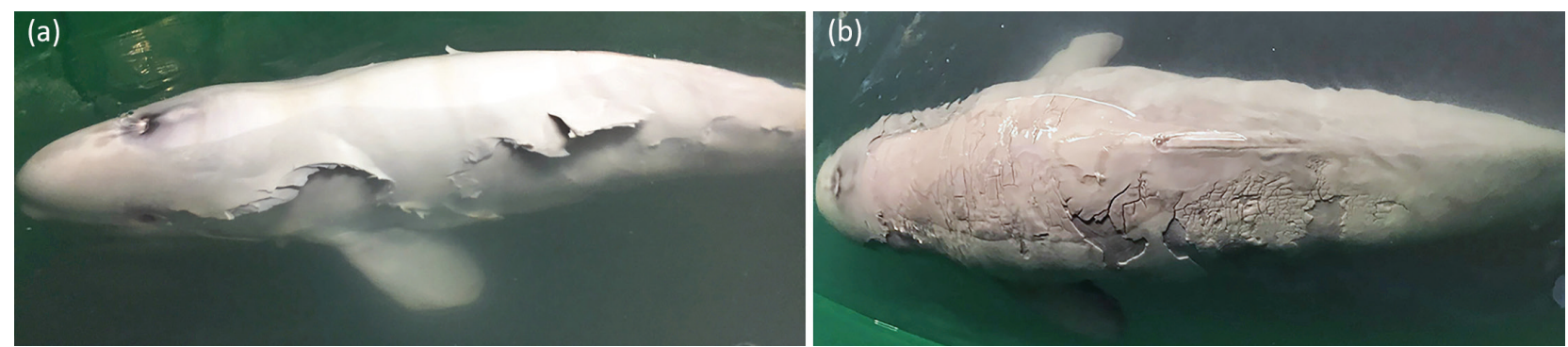

Fig. 4 (a) Post-natal ecdysis of beluga calf (Delphinapterus leucas) DL1750 shortly after admission on 5 October 2017; (b) roughened, cracked, damaged skin starting to slough off the calf on 12 October. 


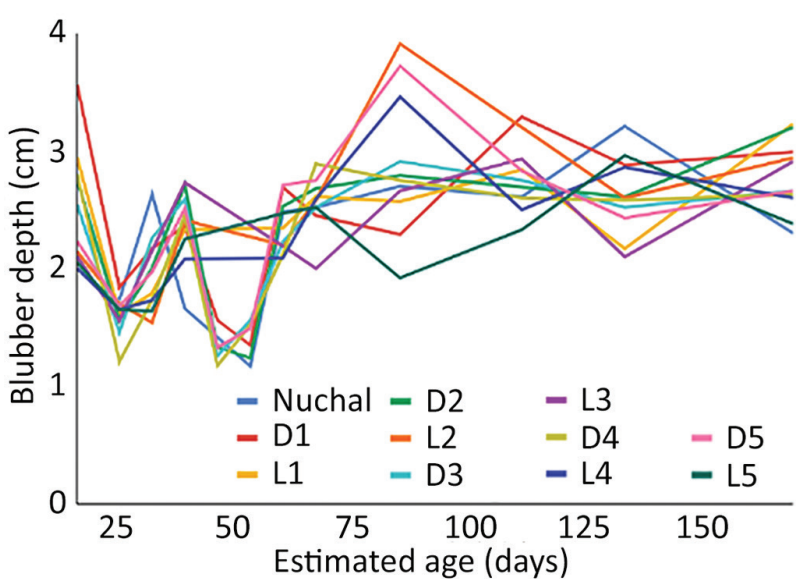

Fig. 5 Blubber depths over time in a stranded beluga calf (Delphinapterus leucas) DL1705 at multiple lateral (L) and dorsal (D) sites used to assess body condition in field projects (Cornick et al. 2016), including the nuchal fat pad; anterior (1) and posterior (2) to the pectoral fin; mid-dorsal ridge (3); mid-abdomen (4); and pelvis (5).

demonstrated in the third CT scan (3 January 2018), which revealed (Fig. 7c) no evidence of pneumothorax or pneumonia as well as resolution of the intracranial ventriculomegaly.

Once the calf's bloodwork and behaviour improved, antibiotics were discontinued on day 25 and antifungals on day 53, though he continued to remain on various gastrointestinal support medications because of recurring problems attributed to the artificial formula. When his activity increased, he needed more space and was moved outside on day 38. While DL1705 successfully recovered from its presenting problems, he was later deemed non-releasable after 97 days of care because of his inability to survive on his own and the risk of recurrence of his pneumothorax. On 9 May 2018, he was transferred to a zoological facility, to live with other belugas, for long-term care.

\section{Discussion}

The trauma of the stranding event caused external physical injuries in both calves and likely resulted in pneumonia, a common complication in stranded cetaceans (Bossart et al. 2013). The hard surface of a beach inhibits their chest expansion during inhalation, which can result over time in poor ventilation, carbon dioxide build-up, hypoxia, respiratory acidosis, sequestration of bacteria and, ultimately, poor vascular tissue circulation (Geraci \& Lounsbury 1993; Díaz-Delgado et al. 2018; St. Leger et al. 2018; Fahlman et al. 2021). Animals may strand in an unusual orientation, making it difficult for them to adequately raise the blowhole to avoid inhaling water. While

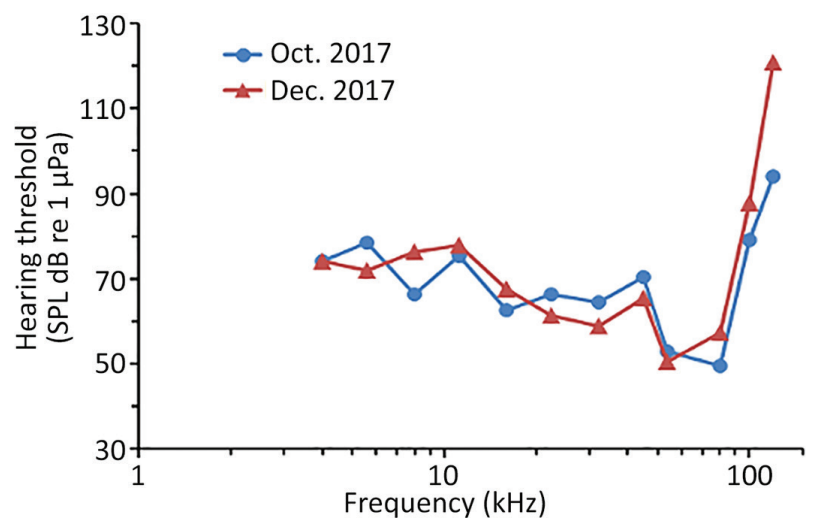

Fig. 6 Audiograms from beluga calf (Delphinapterus leucas) DL1705, adapted from Mooney et al. (2020).

an infectious disease likely caused their pneumonia, both calves were negative for diseases of concern (avian influenza, Brucella spp. and morbillivirus) and their respiratory symptoms improved following antibiotic treatment. Additionally, both animals suffered from various gastrointestinal issues, including constipation and gas, which were treated with a combination of formula adjustments adding water, probiotics, laxatives, anti-gas medicine, enzymes and enemas to aid in passage of contents, digestion of formula and minimization of gas build-up. At the time, these problems were attributed to the formula being artificial and the use of antibiotics, both of which can be associated with negative impacts to the gastrointestinal system, including bloat and malabsorption (Seegraber \& Morrill 1986; Bell et al. 2011; Heinze et al. 2014; Vangay et al. 2015; Bayne \& Edmondson 2020). Additionally, air was visibly introduced during tubing and was audibly being sucked in during nursing. However, DL1705 continued to have intermittent gastrointestinal issues even after antibiotic treatment was discontinued and was weaned to whole fish, suggesting that there may have been additional causes in his case.

DL1202's greatest challenges likely stemmed from his young age at stranding, minimal time spent with his mother and his apparent prematurity. The calf's age estimate and assumed prematurity were supported by the original morphological observations, serum chemistry results, behaviour and post-mortem analysis of tissues (Table 1). Based on the initial exam and diagnostic test results, we suspected that DL1202 never nursed and, therefore, did not receive colostrum, containing maternal antibodies. Because cetaceans have epitheliochorial placentation, which prevents the pre-partum transfer of antibodies, this calf was immunocompromised (Ruiz et al. 2009). This failure of passive transfer predisposes neonates such as DL1202 to life-threatening infections (Tizard 1992; LeBert et al. 2017), such as the pathogens associated with 

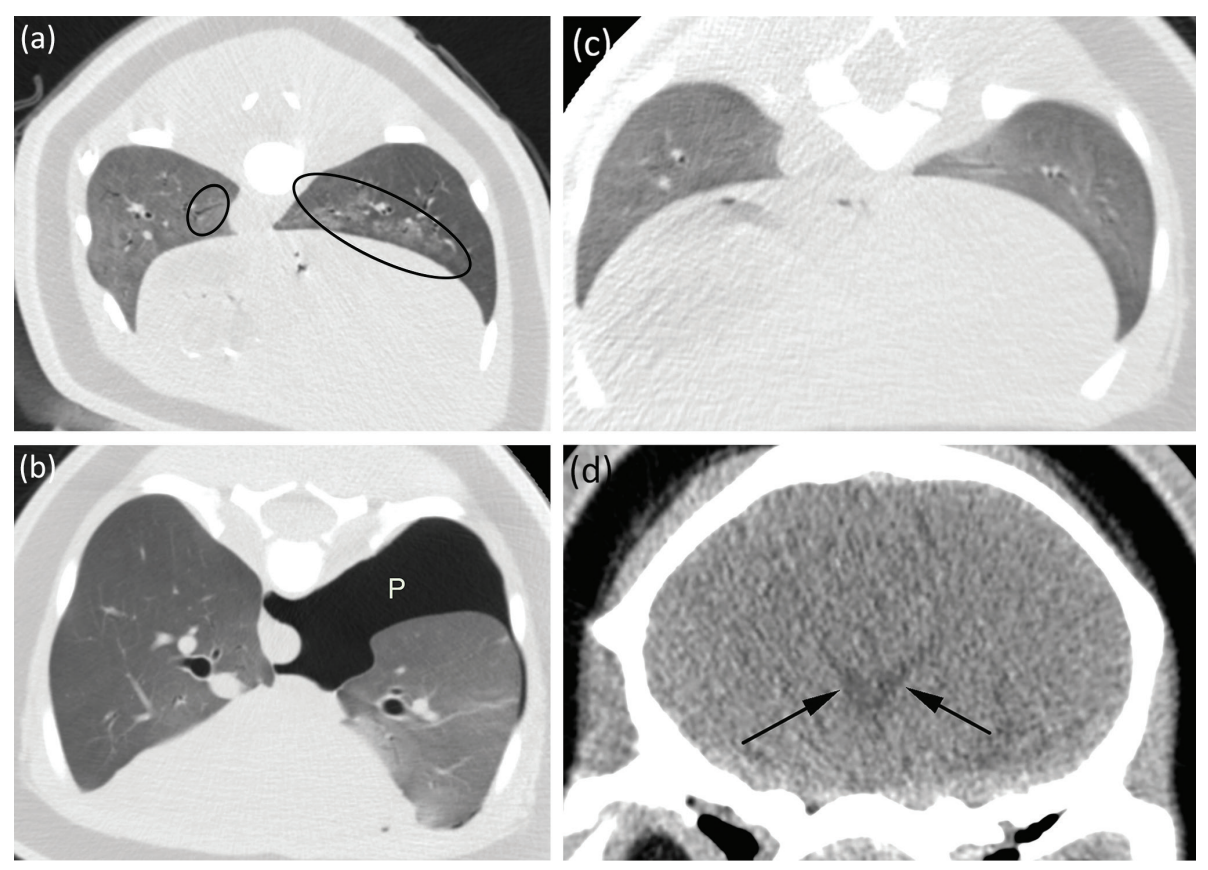

Fig. 7 Select CT scans of stranded beluga calf (Delphinapterus leucas) DL1705 (the patient's left side is on the right side of the images): (a) peribronchial infiltrates (indicated by ovals) on 12 October 2017; (b) left-sided pneumothorax (P) on 16 November 2017; (c) resolved pneumonia and pneumothorax on 3 January 2018; (d) mild hydrocephalus (indicated by arrows) in the lateral ventricles seen on the initial scan of DL1705's head, taken on 12 October 2017; the condition improved and finally resolved on subsequent scans.

his pleuropneumonia, pericarditis, bronchopneumonia and gastrointestinal fungal infections. While no overt signs of stress were observed during the time in rehabilitation, retrospective analysis of DL1202's serum indicated elevated cortisol (Table 5), distinctly higher than DL1705's, whose cortisol, while elevated upon admission after stranding, quickly decreased to, and remained at, levels $(0.637-2.630 \mathrm{ug} / \mathrm{dl})$ similar to baseline levels $(1.80 \pm 0.71$ $\mathrm{ug} / \mathrm{dl}$ ) in adult belugas in a zoological facility (Schmitt et al. 2010). With the benefit of retrospect, DL1202's recovery was always less likely than DL1705, though not impossible. Rehabilitating cetacean stranders is always an uphill battle and gets harder and harder the younger they are. Post-mortem analysis of DL1202's tissues indicated that he was even more premature than initially assumed and had a severe lack of passively acquired antibodies. In light of the particular challenges imposed by this prematurity, the benefits of more aggressive antimicrobial therapy and gastrointestinal support likely would have outweighed the risks of complications, improving his odds of survival. These findings informed our treatment of DL1705, allowing the team to pursue such therapeutic options more confidently.

Some of DL1705's unique medical concerns included an early natal ecdysis, hydrocephalus and spontaneous pneumothorax.
Beluga calves undergo a post-natal ecdysis or moult at 2-4 months of age (pers. comm., S. Aibel), losing the entire layer of neonatal skin, revealing smooth, intact skin underneath, similar to that seen in southern right whales (Eubalaena australis; Reeb et al. 2005). Less than a week after admission at less than a month of age, DL1705 began sloughing centimetre-thick skin, more than a kilogram a day for several days (Fig. 4). The underlying, newly exposed skin was rough and developed fissures that extended to just above the blubber, suggesting that the skin was not mature. In this case, the ecdysis may have been accelerated by the abrupt change in his physical environment, which included warmer, less saline water, conditions that appear to cause dermatological changes in beluga and other cetaceans (St. Aubin et al. 1990; Duignan et al. 2020; Pitman et al. 2020). Physical trauma by the stranding event, susceptibility of cetacean skin to dehydration (Oh et al. 2015; St. Leger et al. 2018) and the impact of stress on skin condition (Peters 2016) would have further contributed to skin damage. Fortunately, none of the fissures exposed blubber or muscle, and within a few weeks, the thin damaged outermost layer peeled away, revealing smooth, healthy skin.

CT scans were originally pursued to better assess, track and make treatment decisions regarding DL1705's pneumonia; however, they also revealed two subclinical 
medical conditions. In addition to pneumonia, the first scan revealed an accumulation of cerebrospinal fluid within the brain, also known as hydrocephalus. This condition can be due to an obstruction caused by congenital defects, infectious diseases, exposure to toxins, other conditions that impair the normal flow or excessive production (de Stefani et al. 2011 ; Biel et al. 2013). In cetaceans, hydrocephalus has been associated with Brucella spp. infection (St. Leger 2007; Langan 2016), but congenital hydrocephalus has also been reported in a bottlenose dolphin (Tursiops truncates; Corpa et al. 2004) born at a zoological facility where the dolphins were healthy, but testing for Brucella spp. was not pursued. DL1705 tested negative for exposure to Brucella spp. on both serological and molecular assays. DL1705's hydrocephalus was mild and reduced in size in subsequent scans, suggesting a transient cause, an anatomic anomaly that became less significant as he grew, or a normal variant in beluga calves of that age.

The second CT scan revealed a pneumothorax, which is an abnormal collection of air in the pleural space between the lung and the chest wall that results in collapse of lung tissue. Causes include trauma, iatrogenic complications of medical intervention (i.e., biopsy or needle insertion) and lung disease, or it may occur spontaneously, and can result in chest pain, shortness of breath and a decrease in respiratory efficiency (Zarogoulidis et al. 2014). This condition has been previously reported in cetaceans in association with pulmonary abscesses, fine-needle aspirations and stranding events and can also occur without an identifiable cause (Mueller \& Geraci 1977; Brouwer 1981; Walsh \& Gearhart 2001; Reidarson 2007; Langan 2009; Fernández et al. 2017; Díaz-Delgado et al. 2018). In afflicted cetaceans, a pneumothorax often results in an abnormal swimming orientation due to altered buoyancy, and they float with the affected side up (Walsh \& Gearhart 2001). However, DL1705 did not list to one side and continued to float evenly in the water column. In retrospect, there were clinical signs consistent with a pneumothorax that were originally attributed to other problems. Between the first two CT scans, the calf had become increasingly positively buoyant, riding higher in the water column, consistent with the collection of excessive gas in the gastrointestinal system. This was suspected to be associated with digestive difficulties with the artificial formula and aerophagia resulting from the calf's inefficient suckling. Also, during this time, an increased respiratory rate (Fig. 3) was attributed to the pain associated with colic but was likely associated with the altered respiratory ability. Following the pneumothorax, on auscultation, there was a notable difference when listening to the affected versus the unaffected lung, which decreased over time and coincided with the body's reabsorption of the air in the pleural space. A specific inciting cause of DL1705's pneumothorax was not identified, and it resolved without treatment. However, if the pneumothorax were to recur, this could affect the calf's ability to dive (Reidarson 2007) and catch food, which was one of the factors that contributed to the non-releasable designation.

DL1705's audiogram overlapped with Bristol Bay beluga audiograms and was similar to captive belugas with 'normal' hearing (Mooney et al. 2018; Mooney et al. 2020), suggesting this animal also had 'normal' hearing similar to many other belugas. Initial data impressions indicated that the animal did hear well from 4 to $128 \mathrm{kHz}$ and was particularly sensitive to sounds at 54 and $80 \mathrm{kHz}$. The animal also heard lower frequencies (4-16 kHz) reasonably well. He seemingly did not hear as high in frequency as some Bristol Bay belugas, but a large portion of that population also only hears up to $120-128 \mathrm{kHz}$ (or lower), similar to DL1705. This range of hearing and its overall sensitivity would suggest the animal could hear communication signals well. It would also be able to detect natural and anthropogenic sounds. The October and December hearing test results were similar, reflecting the consistency of the method and the stability of the animal's hearing. The two acoustic test results were similar despite moving the tests from the indoor to the outdoor pool, suggesting that both locations provide similar and good locations for a stranded animal's auditory health. Hearing and acoustics are the primary means that belugas and other odontocetes communicate and investigate their surroundings (Au 1993, 2000); sounds are key to many natural beluga behaviours and interactions (Schevill 1949; Sjare \& Smith 1986). The 'good' auditory results for DL1705 imply that the animal should develop normally with respect to acoustic behaviour and sensory biology.

After five weeks of care, DL1705 was doing well enough to be taken off antibiotics and moved to an outdoor pool enclosure. Following a formal process by NOAA Fisheries, he was designated non-releasable because of his nutritional and social dependency on human care as well as the risk of recurrence of pneumothorax. A cause for DL1705's stranding has not been determined as there was no evidence of pre-existing disease or trauma, and he was in reasonable body condition. The calf continues to have periodic gastrointestinal motility disorder, and it is possible that he has an undiagnosed congenital or developmental problem. Being a full-term calf, physically and immunologically robust, likely contributed to DL1705's successful recovery from problems associated with stranding. Early medical intervention with broader spectrum, more powerful antibiotics, antifungals, fluids and nutritional supplementation, without waiting for the identification of specific pathogens or specific diagnosis, likely 
also contributed to case success. Familiarity with nursing may have contributed to the calf quickly adapting to bottle feeding, which reduced the need for, and risks associated with, frequent tubing. Finally, the experience of the first case and the depth of expertise of the team made it possible to identify and mitigate problems early.

\section{Conclusions}

These cases provided a wealth of information on the beluga populations that the calves originate from and novel information about wild beluga neonates, and produced several notable achievements. Both cases provided the opportunity to investigate diseases of concern (avian influenza, Brucella spp., herpesvirus, cetacean morbillivirus, Neospora caninum, Toxoplasma gondii and Sarcocystis neurona) as well as closely track several physiologic and metabolic parameters of beluga neonates. DL1705 was the first wild beluga calf, and the first beluga from the endangered CI population, to have a hearing test. Additionally, DL1705 provided a unique opportunity to look at beluga calf neonatal anatomy via CT scan and to track changes in skin over time. While DL1202 was the first stranded beluga calf to be cared for in Alaska and survived longer than any other recorded case in the world at the time, DL1705 was the first successful rehabilitation of a stranded beluga calf. Once thought to be close to impossible, these cases demonstrate the ability to care for and, in DL1705's case, rehabilitate stranded beluga calves, providing another tool to assist in the conservation of endangered populations.

\section{Approvals and permits}

These efforts were carried out in accordance with the requirements of the ASLC-NOAA/National Marine Fisheries Service Stranding Agreement and NOAA's MMHSRP Marine Mammal Protection Act/Endangered Species Act \#18786-02. Animal care and data gathering protocols were developed by ASLC veterinarians and reviewed and approved by NOAA Fisheries staff and veterinarians.

\section{Acknowledgements}

The authors thank the dedicated animal care and veterinary staff from the ASLC, Georgia Aquarium, Mystic Aquarium, SeaWorld, John G. Shedd Aquarium, the Texas Marine Mammal Stranding Network and Vancouver Aquarium, who provided direct support, advice and funds for the care of these beluga calves. The authors further thank numerous colleagues who shared their clinical experiences and knowledge of neonatal cetacean care; scientific advisors who provided rapid feedback on diagnostic results at no cost; and NOAA personnel who facilitated specific health assessments and managed the decision regarding releasability. This constitutes scientific manuscript contribution \#298 from the Sea Research Foundation, Inc.

\section{Funding}

The ASLC, Georgia Aquarium, Mystic Aquarium, SeaWorld, John G. Shedd Aquarium, the Texas Marine Mammal Stranding Network and Vancouver Aquarium self-funded the cost of travel and salaries for their staff. Additional funding was provided by the Prescott Grant Program, Prescott Emergency Grant Program, SeaWorld Busch Gardens Conservation Fund and individual and corporate donations to the ASLC Center wildlife response programme.

\section{Disclosure statement}

The authors report no conflict of interest.

\section{References}

ANSI (American National Standards Institute) 2018. Procedure for determining audiograms in toothed whales through evoked potential methods. Melville, NY: American National Standards Institute.

Au W. 1993. The sonar of dolphins. New York: Springer.

$\mathrm{Au}$ W. 2000. Hearing in whales and dolphins: an overview. In W. Au et al. (eds.): Hearing by whales and dolphins. Pp. 1-42. New York: Springer.

Bayne J.E. \& Edmondson M.A. 2020. Diseases of the gastrointestinal system. In D. Pugh et al. (eds.): Sheep, goat, and cervid medicine. 3rd edn. Pp. 63-96. Philadelphia, PA: Elsevier.

Bekkali N., Hamers S.L., Schipperus M.R., Reitsma J.B., Valerio P.G., Van Toled, L. \& Benninga M.A. 2008. Duration of meconium passage in preterm and term infants. Archive of Disease in Childhood_Fetal Neonatal Edition 93, F376-F379, doi: 10.1136/adc.2009.159442.

Bell K.M., Rutherfurd S.M., Cottam Y.H. \& Hendriks W.H. 2011 . Evaluation of two milk replacers fed to hand-reared cheetah cubs (Acinonyx jubatus): nutrient composition, apparent total tract digestibility, and comparison to maternal cheetah milk. Zoo Biology 30, 412-426, doi: 10.1002/ zoo.20344.

Biel M., Kramer M., Forterre F., Jurina K., Lautersack O., Failing K. \& Schmid M.J. 2013. Outcome of ventriculoperitoneal shunt implantation for treatment of congenital internal hydrocephalus in dogs and cats: 36 cases (2001-2009). Journal of the American Veterinary Medical Association 242, 948-958, doi: 10.2460/javma.242.7.948. 
Bossart G.D., Hurley W., Biedenbach G., Denny M., Borkowski R., Goricki C., Searcy E., Roberts K. \& Reif J. 2013. Pathologic findings in stranded cetaceans from northeastern Florida. The Journal of Infectious Diseases 1, 36-50.

Brouwer L. 1981. Subcutaneous emphysema in a beluga whale. Paper presented at the 12th Annual Conference of the International Association for Aquatic Animal Medicine, 3-6 May, Mystic, CT.

Castellote M., Mooney T.A., Quakenbush L., Hobb, R., Goertz C. \& Gaglione E. 2014. Baseline hearing abilities and variability in wild beluga whales (Delphinapterus leucas). Journal of Experimental Biology 217, 1682-1691, doi: 10.1242/jeb.093252.

Colegrove K., Venn-Watson S., Litz J., Kinsel M., Terio K., Fougeres E., Ewing R., Pabst D., McLellan W., Raverty S., Saliki J., Fire S., Rappucci G., Bowen-Stevens S., Noble L., Costidis A., Barbieri M., Field C., Smith S., Carmichael R.H., Chevis C., Hatchett W., Shannon D., Tumlin M., Lovewell G., McFee W. \& Rowles T.K. 2016. Fetal distress and in utero pneumonia in perinatal dolphins during the northern Gulf of Mexico unusual mortality event. Diseases of Aquatic Organisms 119, 1-16, doi: 10.3354/dao02969.

Cornick L.A., Quakenbush L.T., Norman S.A., Pasi C., Maslyk P., Burek K.A., Goertz C.E.C. \& Hobbs R.C. 2016. Seasonal and developmental differences in blubber stores of beluga whales in Bristol Bay, Alaska using high-resolution ultrasound. Journal of Mammalogy 97, 1238-1248, doi: 10.1093/ jmammal/gyw074.

Corpa J.M., Peris B., Palacio J., Liste F. \& Ribes V. 2004. Hydrocephalus in a newborn bottlenosed dolphin (Tursiops truncatus). Veterinary Record 155, 208-210, doi: 10.1136/ vr.155.7.208.

Dalton L. 2007. Reproductive biology of the beluga whale (Delphinapterus leucas). Paper presented at the 38th Annual Conference of the International Association for Aquatic Animal Medicine, 5-9 May, Orlando, FL.

Davison A.J., Nielsen O., Subramaniam K., Jacob J.M., Romero C.H., Burek-Huntington K.A. \& Waltzek T.B. 2017. Genome sequence of an alphaherpesvirus from a beluga whale (Delphinapterus leucas). Genome Announcements 5, e01100-17, doi: 10.1128/genomeA.01100-17.

Dearolf J.L., McLellan W.A., Dillaman R.M., Frierson D. \& Pabst D.A. 2000. Precocial development of axial locomotor muscle in bottlenose dolphins (Tursiops truncatus). Journal of Morphology 244, 203-215, doi: 10.1002/(SICI) 10974687(200006)244:3<203::AID-JMOR5>3.0.CO;2-V.

De Guise S., Giard J., Patenaude R., Michaud R., Ramirez K., Beland P., Turgeon P., Pelletier E. 1992. Rescue of a newborn beluga whale in the St. Lawrence Estuary, Quebec, Canada. Paper presented at the Conference of the International Association for Aquatic Animal Medicine, 18-22 May, Hong Kong.

Dennison S. \& Saviano P. 2018 . Diagnostic imaging. In F.M.D. Gulland et al. (eds.): CRC handbook of marine mammal medicine. 3rd edn. Pp. 537-551. Boca Raton, FL: CRC Press,

de Stefani A., de Risio L., Platt S.R., Matiasek L., Lujan-FeliuPascual A. \& Garosi L.S. 2011. Surgical technique, postoperative complications and outcome in 14 dogs treated for hydrocephalus by ventriculoperitoneal shunting: ventriculoperitoneal shunting in dogs. Veterinary Surgery 40, 183-191, doi: 10.1111/j.1532-950X.2010.00764.x.

Díaz-Delgado J., Fernández A., Sierra E., Sacchini S., Andrada M., Vela A.I., Quesada-Canales Ó., Paz Y., Zucca D., Groch K. \& Arbelo M. 2018. Pathologic findings and causes of death of stranded cetaceans in the Canary Islands (2006-2012). PLoS One 13, e0204444, doi: 10.1371/journal.pone.0204444.

Dierauf L.A., Dougherty S.A. \& Baker B. 1984. Neonatal hyperbilirubinemia in harbor seals (Phoca vitulina richardsi). Journal of Zoo and Wildlife Medicine 15, 55-59, doi: $10.2307 / 20094685$.

Duignan P.J., Stephens N.S. \& Robb K. 2020. Fresh water skin disease in dolphins: a case definition based on pathology and environmental factors in Australia. Nature Scientific Reports 10, article no. 21979, doi: 10.1038/ s41598-020-78858-2

Fahlman A., Brodsky M., Rocho-Levine J., Garcia-Parraga D., Ivančić M., Camarena C., Ibarra L. \& Rocabert J. 2021. Respiratory changes in stranded bottlenose dolphins (Tursiops truncatus). Journal of Zoo and Wildlife Medicine 52, 49-56, doi: 10.1638/2020-0033.

Feinholz D.M. \& Atkinson S. 2000. Possible aetiologies of yellow coloration in dolphin calves. Aquatic Mammals 26, 191-195.

Fernández A., Sierra E., Díaz-Delgado J., Sacchini S., Sánchez-Paz Y., Suárez-Santana C., Arregui M., Arbelo M. \& de Quirós Y.B. 2017. Deadly acute decompression sickness in Risso's dolphins. Nature Scientific Reports 7, article no. 13621, doi: 10.1038/s41598-017-14038-z.

Finneran J.J., Houser D.S. \& Schlundt C.E. 2007. Objective detection of bottlenose dolphin (Tursiops truncatus) steadystate auditory evoked potentials in response to AM/FM tones. Aquatic Mammals 33, 43-54.

Flower J.E., Langan J.N., Nevitt B.N., Chinnadurai S.K., Stacey R., Ivančić M. \& Adkesson M.J. 2018. Neonatal critical care and hand-rearing of a bottlenose dolphin (Tursiops truncatus) calf. Aquatic Mammals 43, 482-490, doi: 10.1578/ AM.44.5.2018.482.

Geraci J.R. \& Lounsbury V.J. 1993. Marine mammals ashore: a field guide for strandings. Galveston: Sea Grant College Program, Texas A\&M University.

Gulland F.M.D., Dierauf L.A. \& Whitman, K.L. 2018. Normal hematology and serum chemistry ranges. In F.M.D. Gulland et al. (eds.): CRC handbook of marine mammal medicine. 3rd edn. Pp. 1002-1029. Boca Raton, FL: CRC Press.

Heinze C.R., Freeman L.M., Martin C.R., Power M.L. \& Fascetti A.J. 2014. Comparison of the nutrient composition of commercial dog milk replacers with that of dog milk. Journal of the American Veterinary Medical Association 244, 1413-1422, doi: 10.2460/javma.244.12.1413.

Houser D.S. \& Finneran J.J. 2006. Variation in the hearing sensitivity of a dolphin population determined through the use of evoked potential audiometry. The Journal of the Acoustical Society of America 120, 4090-4099, doi: $10.1121 / 1.2357993$.

Jaramillo-Legorreta A., Rojas-Bracho L., Brownell R.L., Read A.J., Reeves R.R., Ralls K. \& Taylor B.L. 
2007. Saving the vaquita: immediate action, not more data. Conservation Biology 21, 1653-1655, doi: $10.1111 /$ j.1523-1739.2007.00825.x.

Krasnov V.V., Bel'kovich V.M. \& Chernetskii A.D. 2009. Formation of behavior in the White Sea beluga calf, Delphinapterus leucas, during early postnatal ontogenesis. Russian Journal of Marine Biology 35, 53-59, doi: 10.1134/ S1063074009010088.

Lakshmanan J. \& Ross M.G. 2008. Mechanism(s) of in utero meconium passage. Journal of Perinatology 28 (Suppl. 3), S8-S13, doi: 10.1038/jp.2008.144.

Langan J.N. 2009. Diagnosis and management of a pulmonary abscess in a bottlenose dolphin (Tursiops truncatus). Paper presented at the 40th Annual Conference of the International Association for Aquatic Animal Medicine, 2-6 May, San Antonio, TX.

Langan J.N. 2016. Antemortem diagnosis of hydrocephalus and hearing loss associated with chronic Brucella infection in a stranded rehabilitated bottlenose dolphin (Tursiops truncatus). Paper presented at the Conference of the International Association for Aquatic Animal Medicine, 21-26 May, Virginia Beach, VA.

LeBert C., McGrew S., Venn-Watson S., Dold C., Nollens H. \& Jensen E. 2017. Evaluation of rapid pool-side tests for diagnosis of failure of passive transfer in bottlenose dolphin (Tursiops truncatus) neonates. Paper presented at the 48th Annual Conference of the International Association for Aquatic Animal Medicine, 20-24 May, Cancun, Mexico.

Le Net R., Couture É., Lasby B., Wimmer T., Haulena M., Lair S., Giard J., Michaud R., Binder T., Elliott I. \& Lesage V. 2019. Medical aspects of the translocation to the St. Lawrence Estuary (Quebec, Canada) of a beluga (Delphinapterus leucas) trapped in a river. Paper presented at the Second International Workshop on Beluga Whale Research and Conservation, 12-14 March, Mystic, CT.

McGuire T. \& Stephens A. 2017. Photo-identification of beluga whales in Cook Inlet, Alaska: summary and synthesis of 2005-2015 data. Anchorage: LGL Alaska Research Associates, Inc.

Meegan J., Field C., Sidor I., Romano T., Casinghino S., Smith C.R., Kashinsky L., Fair P.A., Bossart G., Wells R. \& Dunn J.L. 2010. Development, validation, and utilization of a competitive enzyme-linked immunosorbent assay for the detection of antibodies against Brucella species in marine mammals. Journal of Veterinary Diagnostic Investigation 22, 856-862, doi: 10.1177/104063871002200603.

Michaud R., Giard J., Michaud A. \& Moisan M. 2020. Translocation of live-stranded newborn St. Lawrence Estuary belugas (Delphinapterus leucas) for adoption by nearby females: a review of past responses, and assessment of feasibility and risks. Tadoussac, QC: Fisheries and Oceans Canada, Canadian Science Advisory Secretariat.

Miller M.A., Gardner I.A., Packham A., Mazet J.K., Hanni K.D., Jessup D., Estes J., Jameson R., Dodd E., Barr B.C., Lowenstine L.J., Gulland F.M. \& Conrad P.A. 2002. Evaluation of an indirect fluorescent antibody test (IFAT) for demonstration of antibodies to Toxoplasma gondii in the sea otter (Enhydra lutris). Journal of Parasitology 88, 594-599, doi: 10.2307/3285456.
Mooney T.A., Castellote M., Jones I., Rouse N., Rowles T., Mahoney B. \& Goertz C.E.C. 2020. Audiogram of a Cook Inlet beluga whale (Delphinapterus leucas). The Journal of the Acoustical Society of America 148, 3141-3148, doi: $10.1121 / 10.0002351$.

Mooney T.A., Castellote M., Quakenbush L., Hobb, R., Gaglione E. \& Goertz C. 2018. Variation in hearing within a wild population of beluga whales (Delphinapterus leucas). Journal of Experimental Biology 221, jeb171959, doi: 10.1242/jeb.171959.

Mooney T.A., Yamato M. \& Branstetter B.K. 2012. Hearing in cetaceans: from natural history to experimental biology. Advances in Marine Biology 63, 197-246, doi: 10.1016/ B978-0-12-394282-1.00004-1.

Morgan L.W., Jakush J.L., Simpson A., Norman M.M., Pabst D.A. \& Simmons S. 2009. Evaluation of hematologic and biochemical values for convalescing seals from the coast of Maine. Journal of Zoo and Wildlife Medicine 40, 42 1-429, doi: 10.1638/2007-0032.1.

Mueller R. \& Geraci J.R. 1977. Unusual disease findings in a stranded pilot whale. Paper presented at the Conference of the International Association for Aquatic Animal Medicine, 18-21 April, Boston, MA.

Nachtigall P.E. 2005. Hearing measurements from a stranded infant Risso's dolphin, Grampus griseus. Journal of Experimental Biology 208, 4181-4188, doi: 10.1242/jeb.01876.

Nachtigall P.E., Mooney T.A., Taylor K.A. \& Yuen M.M.L. 2007. Hearing and auditory evoked potential methods applied to odontocete cetaceans. Aquatic Mammals 33, 6-13, doi: 10.1578/AM.33.1.2007.6.

National Marine Fisheries Service 2008. Endangered and threatened species; endangered status for the Cook Inlet beluga whale. Federal Register 73, 62919-62930.

National Marine Fisheries Service 2016. Recovery plan for the Cook Inlet beluga whale (Delphinapterus leucas). Juneau, AK: National Marine Fisheries Service, Alaska Region, Protected Resources Division.

Oh J.W., Chung O., Cho Y.S., MacGregor G.R. \& Plikus M.V. 2015. Gene loss in keratinization programs accompanies adaptation of cetacean skin to aquatic lifestyle. Experimental Dermatology 24, 572-573, doi: 10.1111/exd.12756.

Osborn S., Dalton L., Dold C. \& Robeck T. 2012. Management of twin pregnancy and perinatal concerns in a beluga (Delphinapterus leucas). Journal of Zoo and Wildlife Medicine 43, 193-196, doi: 10.1638/2011-0161.1.

Peters E.M.J. 2016. Stressed skin?-a molecular psychosomatic update on stress-causes and effects in dermatologic diseases. Journal der Deutschen Dermatologischen Gesellschaft 14, 233-252, doi: 10.1111/ddg.12957.

Pitman R.L., Durban J.W., Joyce T., Fearnbach H., Panigada S. \& Lauriano G. 2020. Skin in the game: epidermal molt as a driver of long-distance migration in whales. Marine Mammal Science 36, 565-594, doi: $10.1111 / \mathrm{mms} .12661$.

Puryear W.B., Keogh M., Hill N., Moxley J., Josephson E., Davis K.R., Bandoro C., Lidgard D., Bogomolni A., Levin M., Lang S., Hammill M., Bowen D., Johnston D.W., Romano T., Waring G. \& Runstadler J. 2016. Prevalence of influenza A virus in live-captured North Atlantic 
gray seals: a possible wild reservoir. Emerging Microbes $\theta$ Infections 5, e81, doi: 10.1038/emi.2016.77.

Reeb D., Duffield M. \& Best P.B. 2005. Evidence of postnatal ecdysis in southern right whales (Eubalaena australis). Journal of Mammalogy 86, 131-138, doi: 10.1644/1545-1542(2005)086<0131:EOPEIS>2.0.CO;2.

Reidarson T.H. 2007. Air third spacing phenomena in two cetaceans. Paper presented at the 38th Annual Conference of the International Association for Aquatic Animal Medicine, 5-9 May, Orlando, FL.

Reidarson T.H., McBain J.F. \& Yochem P.K. 2001. Medical and nutritional aspects of a rehabilitating California gray whale calf. Aquatic Mammals 27, 215-221.

Robeck T.R., Schmitt T.L. \& Osborn S. 2015. Development of predictive models for determining fetal age-at-length in belugas (Delphinapterus leucas) and their application toward in situ and ex situ population management. Marine Mammal Science 31, 591-611, doi: 10.1111/mms.12180.

Ruiz C.L., Nollens H.H., Venn-Watson S., Green L.G., Wells R.S., Walsh M.T., Nolan E.C., McBain J.F. \& Jacobson E.R. 2009. Baseline circulating immunoglobulin G levels in managed collection and free-ranging bottlenose dolphins (Tursiops truncatus). Developmental e Comparative Immunology 33, 449-455, doi: 10.1016/j.dci.2008.09.002.

Saliki J.T. \& Lehenbauer T.W. 2001. Monoclonal antibody-based competitive enzyme-linked immunosorbent assay for detection of morbillivirus antibody in marine mammal sera. Journal of Clinical Microbiology 39, 18771881, doi: 10.1128/JCM.39.5.1877-1881.2001.

Schevill W.E. 1949. Underwater listening to the white porpoise (Delphinapterus leucas). Science 109, 143-144, doi: 10.1126/science.109.2824.143.

Schmitt T.L., St. Aubin D.J., Schaefer A.M. \& Dunn J.L. 2010. Baseline, diurnal variations, and stress-induced changes of stress hormones in three captive beluga whales, Delphinapterus leucas. Marine Mammal Science 26, 635-647, doi: 10.1111/j.1748-7692.2009.00366.x.

Seegraber F.J. \& Morrill J.L. 1986. Effect of protein source in calf milk replacers on morphology and absorptive ability of small intestine. Journal of Dairy Science 69, 460-469, doi: 10.3168/jds.S0022-0302(86)80424-6.

Shelden K.E.W. \& Wade P.R. 2019. Aerial surveys, distribution, abundance, and trend of belugas (Delphinapterus leucas) in Cook Inlet, Alaska, June 2018. Seattle, WA: Alaska Fisheries Science Center, National Oceanic and Atmospheric Administration, National Marine Fisheries Service.

Sjare B.L. \& Smith T.G. 1986. The vocal repertoire of white whales, Delphinapterus leucas, summering in Cunningham Inlet, Northwest Territories. Canadian Journal of Zoology 64, 407-415, doi: 10.1139/z86-063.

Spackman E., Senne D.A., Myers T.J., Bulaga L.L., Garber L.P., Perdue M.L., Lohman K., Daum L.T. \& Suarez D.L. 2002. Development of a real-time reverse transcriptase
PCR assay for type A influenza virus and the avian H5 and H7 hemagglutinin subtypes. Journal of Clinical Microbiology 40, 3256-3260, doi: 10.1128/JCM.40.9.3256-3260.2002.

St. Aubin D.J., Smith T.G. \& Geraci J.R. 1990. Seasonal epidermal molt in beluga whales, Delphinapterus leucas. Canadian Journal of Zoology 68, 359-367, doi: 10.1139/ z90-051.

St. Leger J.A. 2007. Hydrocephalus and nonsuppurative meningoencephalitis associated with Brucella $s p$. infection in two live-stranded dolphins. Paper presented at the 38th Annual Conference of the International Association for Aquatic Animal Medicine, 5-9 May, Orlando, FL.

St. Leger J., Raverty S. \& Mena A. 2018. Cetacea. In K.A. Terio et al. (eds.): Pathology of wildlife and zoo animals. Pp. 533-568. Philadelphia, PA: Elsevier.

Stoskopf M.K., Willens S. \& McBain J.F. 2001. Pharmaceuticals and formularies. In F.M.D. Gulland et al. (eds.): CRC handbook of marine mammal medicine. 3rd edn. Pp. 703-722. Boca Raton, FL: CRC Press.

Sweeney J.C., Stone R., Campbell M., McBain J., St. Leger J., Xitco M., Jensen E. \& Ridgway S. 2010. Comparative survivability of Tursiops neonates from three U.S. institutions for the decades 1990-1999 and 2000-2009. Aquatic Mammals 36, 248-261, doi: 10.1578/AM.36.3.2010.248.

Teare A. 1991. Medical record systems for the next century: the case for improved health care through integrated data base. Journal of Zoo and Wildlife Medicine 22, 389-391.

Tizard I. 1992. Veterinary immunology. Philadelphia, PA: W.B. Saunders Co.

Vangay P., Ward T., Gerber J.S. \& Knights D. 2015. Antibiotics, pediatric dysbiosis, and disease. Cell Host $\theta$ Microbe 17, 553564, doi: 10.1016/j.chom.2015.04.006.

Walsh M.T. \& Gearhart S. 2001. Intensive care. In F.M.D. Gulland et al. (eds.): CRC handbook of marine mammal medicine. 3rd edn. Pp. 689-702. Boca Raton, FL: CRC Press.

Wang D., Zhang X., Wang K., Wei Z., Würsig B., Braulik G.T. \& Ellis S. 2006. Conservation of the baiji: no simple solution. Conservation Biology 20, 623-625, doi: 10.1111/j.1523-1739.2006.00471.x.

Winhall W. 2012. Hand raising and conditioning of neonate beluga whale (Delphinapterus leucas). Soundings 37, 16-21.

Zagzebski K.A., Gulland F.M., Haulena M. \& Lander M.E. 2006. Twenty-five years of rehabilitation of odontocetes stranded in central and northern California, 1977 to 2002. Aquatic Mammals 32, 334-345, doi: 10.1578/ AM.32.3.2006.334.

Zarogoulidis P., Kioumis I., Pitsiou G., Porpodis K., Lampaki S., Papaiwannou A., Katsikogiannis N., Zaric B., Branislav P., Secen N., Dryllis G., Machairiotis N., Rapti A. \& Zarogoulidis K. 2014. Pneumothorax: from definition to diagnosis and treatment. Journal of Thoracic Disease 6, Suppl. 4, S372-S376, doi: 10.3978/j.issn.2072-1439.2014.09.24. 